\title{
KEBERTAHANAN PEREMPUAN SIMALANGGANG MENJADI SINGLE MOTHER
}

\author{
Nofrianti Putri Utami \\ Sosiologia Agama FUAD IAIN Bukittinggi \\ Email: nofriantiutami27@gmail.com \\ Silfia Hanani \\ Sosiologi Agama FUAD IAIN Bukittinggi \\ Email: silfia_hanani@yahoo.com
}

\begin{abstract}
This study aims to determine and analyze the survival of women into a single mother. This was a qualitative research type. Single mothers are respondents in this study. Interview and observation carried out in data collection. The results showed that the task of women becomes more difficult if they become single parents. A woman should have a dual role in her family as a mother and father to her children. Mother is looking for a living for her family and their daily needs. It is concluded that a single mother at the same time must be able to overcome economic, psychological, and social problems in the society environment.
\end{abstract}

Key Words: Single mother, double role

\section{PENDAHULUAN}

Fitrah manusia adalah hidup berdampingan dan hidup berpasangpasangan membangun sebuah keluarga. Keluarga merupakan unit terkecil yang ada di dalam masyarakat. Pada umumnya keluarga dimulai dari perkawinan sepasang laki-laki dan perempuan dewasa. Setelah perkawinan tersebut mulailah mereka hidup bersama membangun rumah tangga dan memiliki anak.

Keluarga memiliki kewajiban untuk memenuhi kebutuhan-kebutuhan untuk anak-anaknya yang meliputi kebutuhan spiritual, psikologis, sandang, pangan dan papannya. Adapun tujuan untuk membentuk keluarga adalah untuk mewujudkan kesejahteraan anggota keluarganya. Dalam konsep keluarga berlaku pembagian tugas peran suami isteri. Salah satu tugas dalam keluarga adalah menjadi orang tua. Segala urusan rumah tangga dan pengasuhan anak menjadi tanggung jawab isteri, sedangkan suami bertugas untuk mencari nafkah agar kebutuhan ekonomi dalam keluarga terpenuhi. Tapi berbeda dengan perempuan yang hanya menghidupi keluarganya seorang diri, yang biasa disebut dengan single mother.

Single mother adalah perempuan yang menjadi orang tua tunggal bagi anak-anaknya sebagai akibat perceraian dan kematian. Tugas perempuan menjadi lebih berat jika menjadi orang tua tunggal (single mother). Setiap perempuan yang sudah menikah pastilah tidak pernah berharap menjadi seorang single mother, keluarga lengkap tetap menjadi idaman setiap perempuan, namun adakalanya 
nasib berkehendak lain (Maripadang, 2013:2). Kenyataannya kondisi ideal tersebut tidak dapat dipertahankan atau diwujudkan. Banyak dari perempuan yang memilih bahkan terpaksa menjadi single mother.

Artikel ini bertujuan untuk mengungkap dan menganalisis kebertahanan singel mother dalam mempertahankan hidup mulai dari memenuhi kebutuhan ekonomi keluarga, menghadapi permasalahan psikologis yang dihadapi dan permasalahan kehidupan sosial ditengah-tengah masyarakat.

\section{METODE PENELITIAN}

Untuk pengumpulan data dalam penelitian ini digunakan teknik interview kepada beberapa informan dan melakukan observasi terhadap beberapa rumah tangga single mother di Nagari Simalanggang Kecamatan Payakumbuh. Adapun subjek penelitian 5 orang single mother dimana 2 orang telah kehilangan pasangannya disebabkan oleh perceraian dan 3 orang lainnya disebabkan oleh kematian.

Berdasarkan masalah dan tujuan penelitian, maka penelitian ini digolongkan dalam penelitian kualitatif deskriptif. Penelitian kualitatif cenderung menggunakan kata-kata, baik lisan dan tertulis yang telah dicermati melalui observasi. Metode kualitatif berusaha memahami dan menafsirkan makna suatu peristiwa interaksi tingkah laku manusia dalam situasi tertentu menurut perspektif peneliti sendiri (Husaini dkk, 2007: 121).

\section{HASIL PENELITIAN DAN \\ PEMBAHASAN}

Simalanggang adalah sebuah nagari di Kecamatan Payakumbuh, Kabupaten Lima Puluh Kota, Sumatera Barat. Nagari Simalanggang ini berjarak 5 kilometer dari pusat Kota Payakumbuh. Nagari Simalanggang terbagi dalam empat jorong, yaitu Jorong Koto, Jorong Tabiang Ranah, Jorong Balai Rupih dan Jorong Api-api. Jumlah Penduduk di Nagari Simalanggang ada 4.200 jiwa dengan luas wilayah 3,39 $\mathrm{km}^{2}$. Masyarakat Nagari Simalanggang secara kultutral terdiri dari beberapa suku seperti Picancang, Kutianyie, Payobada, Piliang, Pitopang, Jambak, Simabua, Melayu dan Chaniago. Nagari Simalanggang secara administratif berada di ketinggian 513 meter dari permukaan laut. Sebelah Utara Nagari Simalanggang berbatasan dengan Nagari Koto Tangah, sebelah Selatan berbatasan dengan Nagari Lampasi, sebelah Barat berbatasan dengan Nagari Koto Baru Simalanggang dan sebelah Timur berbatasan dengan Nagari Koto Nan Gadang. Nagari Simalanggang memiliki area pertanian, perkebunan dan peternakan. Tanaman yang banyak ditanam oleh masyarakat sekitar adalah padi, jagung, ubi kayu, buncis, cabai dan sebagainya.

Agama merupakan faktor yang sangat menentukan dalam pembentukan kepribadian masyarakat, agama tidak akan terlepas dari kehidupan masyarakat. Dalam wujudnya sebagai sebuah lembaga di tengah-tengah masyarakat agama sangat diyakini kebenarannya oleh penganutnya. Di Kanagarian Simalanggang semua masyarakat menganut agama Islam (Anjela, 2014: 8). Dalam sebuah keluarga, agama 
merupakan pendidikan pertama dalam membangun rumah tangga dan mendidik anak. agama juga menjadi fondasi dan bekal utama untuk mengarungi kehidupan.

\section{Peran Ganda Single Mother}

Keluarga sebagai sistem sosial mempunyai tugas atau fungsi agar sistem tersebut berjalan. Tugas tersebut berkaitan dengan pencapaian tujuan integritas dan solidaritas serta pola keseimbangan atau pola pemeliharaan dalam keluarga. Keluarga merupakan tempat sosialisasi untuk bekerja, di mana anggota keluarga mempelajari sikap-sikap yang diperlukan dan memasuki pekerjaan yang layak yang memungkinkan keluarga hidup mandiri secara ekonomis (Euis Sunarti, 2001: 8).

Dalam keluarga perlu ada kepala keluarga sebagai tokoh penting yang mengemudikan perjalanan hidup keluarga yang diasuh dan dibinanya, karena keluarga sendiri terdiri dari beberapa orang, maka terjadi interaksi antar pribadi, dan itu berpengaruh terhadap keadaan harmonis dan tidak harmonisnya pada salah seorang anggota keluarga, yang selanjutnya berpengaruh pula terhadap pribadi-pribadi lain dalam keluarga. Namun keadaan ini menjadi berbeda ketika seorang perempuan harus menyandang status sebagai orang tua tunggal bagi anak-anaknya.

Seorang ibu tunggal boleh dikatakan sebagai single mother apabila wanita itu telah kematian suami dan terpaksa meneruskan tugas membesarkan anakanak atau seorang wanita yang telah bercerai dengan suaminya dan diberi hak penjagaan atas anak-anaknya ataupun seorang wanita yang digantung (statusnya tidak jelas) karena tidak diberi nafkah oleh suami untuk mememnuhi hidupnya dan anak- anaknya ataupun seorang wanita dalam proses perceraian yang mungkin akan mengambil masa yang panjang dan anak-anaknya masih dibawah penjagaannya pada waktu ini (Fadillah, 2015: 10)

Seorang single mother harus mengasuh anak-anaknya seorang diri karena kehilangan suami akibat perceraian atau meninggal dunia. Single mother dituntut untuk meluangkan waktunya dan membagi waktunya untuk memberi kasih sayang dan mencari nafkah untuk keluarga dan anak-anaknya. Perempuan single mother dituntut untuk bisa hidup mandiri dan melanjutkan kehidupannya tanpa seorang suami. Dalam kasus perceraian meskipun mantan suami masih memberikan uang nafkah untuk anak-anaknya, tapi ia tidak lagi memberikan uang dalam keadaan cukup untuk memenuhi kebutuhannya sehari-hari. Terlebih mantan suami memilih untuk menikah lagi dan akan membiayai kehidupannya dengan isteri barunya. Para single mother harus pandaipandai dalam membagi waktunya dalam keluarga, ia dituntut untuk mengerjakan seluruh pekerjaan rumah dan harus berusaha mencukupi semua kebutuhan keluarga dan anak-anaknya.

Status single mother menjadikan perempuan sebagai kepala kelurga, dimana perempuan memiliki peran ganda bagi ibu yaitu sebagai orang tua tunggal untuk mengurus anak-anaknya dan ia juga dituntut untuk bekerja guna mencari nafkah untuk memenuhi kebutuhan keluarganya. Menjadi single mother dalam sebuah keluarga tidaklah mudah, karena seorang ibu harus memainkan peran 
ganda dalam keluarganya yaitu menjadi ibu untuk anak-anaknya dan menjadi ayah untuk mencari nafkah memenuhi kebutuhan keluarga dan anak-anaknya.

Seorang single mother yang ditinggal mati oleh suaminya ia akan merasa lebih kesulitan lagi, karena ia tidak bisa bergantung dan mengadu pada suaminya lagi, berbeda dengan seorang single mother yang disebabkan oleh perceraian, ia masih bisa meminta bantuan untuk memenuhi kebutuhan anak-anaknya. Kematian pasangan jelas sangat berpengaruh bagi diri seorang perempuan, pasangan yang ditinggal terpaksa melakukan segala sesuatu pekerjaan keluarga dengan sendirinya tanpa bantuan dari suami. Seorang single mother harus berfikir sendiri bagaimana menghidupi keluarga dan anak-anaknya tanpa harus merepotkan keluarga yang lain. Seorang single mother juga harus bisa mendidik anak-anaknya seorang diri. Single mother harus bertanggung jawab dalam keluarganya baik dalam penyedia keuangan, pemenuhan kebutuhan rumah tangga dan dalam mendidik anak-anaknya.

Keberhasilan seorang single mother dalam mendidik dan menafkahi anakanaknya tergantung pada bagaimana ia bisa membagi waktu antara mencari nafkah dan mendidik anak-anaknya, bagaimana ia bisa menyesuaikan diri dengan masyarakat sekitarnya dan bagaimana seorang single mother bertindak dan bersikap agar tidak di cemooh oleh masyarakat karena statusnya sebagai seorang single mother.

Perempuan single mother memiliki gambaran tentang makna hidup antara lain adalah bisa menjadi individu yang menghargai hidup, bisa menghadapi permasalahan dengan bijak, bisa lebih sabar dalam menghadapi permasalahan dan menjadi individu yang lebih baik. Single mother dituntut harus kuat dalam menjalani kehidupan tanpa sosok seorang suami disampingnya. Ia harus menjadi kuat dihadapan anak-anaknya agar mereka tidak merasa begitu kehilangan sosok ayah di dalam hidupnya.

\section{Alasan Perempuan Menjadi Single Mother}

Jika melihat fenomena di atas, ada berbagai masalah terkait yang terjadi di Nagari Simalanggang Kecamatan Payakumbuh yaitu masalah dalam keluarga antara suami dengan istri. Ada dua alasan yang melatarbelakangi seorang perempuan menjadi single mother, yaitu:

\section{Perceraian}

Di dalam keluarga, perkawinanan melibatkan dua individu dengan kepribadiannya masing-masing dan latar belakang yang berbeda yang berusaha untuk hidup bersama. Yang menjadi alasan terjadinya sebuah perceraian adalah harapan-harapan yang berlebihan yang diharapkan kepada masing-masing pasangan. Harapan ini dapat berupa status sosial dan hubungan-hubungan bersifat seksual, popularitas, jaminan kesehatan, jaminan pekerjaan yang tepat sebagai suami isteri (Nur Fadillah, 2015: 12)

Perceraian bukan suatu peristiwa tunggal, namun perceraian merupakan suatu proses, rangkaian yang potensial membawa pengalaman yang penuh stress yang mulai sebelum perpisahan fisik dan berlanjut setelahnya. Perceraian cenderung mengurangi kesejahteraan 
jangka panjang, terutama bagi pihak pasangan yang tidak menginginkan perceraian tersebut atau tidak ingin menikah kembali. Alasan-alasan dapat mencakup gangguan hubungan orang tua dan anak, keributan dengan bekas pasangan, kesulitan ekonomi, kehilangan dukungan emosional, dan harus pindah dari rumah keluarga.

\section{Kematian}

Seorang perempuan yang telah menyandang status sebagai isteri bisa menjadi single mother ketika suaminya meninggal. Baik itu meninggal karena kecelakan ataupun meninggal karena suatu penyakit yang diderita suaminya. Kematian yang menimpa suami membuat seorang isteri menjadi orang tua tunggal untuk anak-anaknya. Sang ibu harus menjadi lebih kuat lagi karena harus menjadi ayah serta ibu bagi anak-anaknya setelah ditinggal mati oleh suaminya. Disini tidak ada pihak yang menginginkan perpisahan ini, ini terjadi karena takdir, dan isteri harus menerima takdir tersebut dengan menjadi orang tua tunggal untuk anak-anaknya.

Setiap perempuan tidak pernah berharap menjadi orang tua tunggal bagi anak-anaknya, namun adakalanya nasib berkehendak lain. Pada kenyataannya kondisi ideal tersebut tidak selamanya bisa dipertahankan atau diwujudkan karena dua faktor di atas. Mereka harus dengan terpaksa menerima keadaannya sebagai seorang perempuan single mother ( Cahyani, 2016:157)

\section{Kebertahanan Perempuan Single Mother}

Peningkatan kebertahanan single mother menjadi penting sehubungan dengan kemampuan keluarga dalam pemenuhan kebutuhan serta kemampuannya untuk memenuhi perekonomian anggota keluarganya. Kebertahanan tersebut mengacu kepada ketahanan pangan, kecukupan dan kesinambungan akses terhadap pendapatan untuk memenuhi kebutuhan dasar (seperti pendidikan, perumahan dan kebutuhan ekonomi)

Menurut teori struktural fungsional masyarakat merupakan suatu sistem sosial yang terdiri atas bagian-bagian atau elemen yang saling berkaitan dan saling menyatu dalam keseimbangan. Perubahan yang terjadi pada satu bagian akan membawa perubahan pula terhadap bagian yang lain. Asumsi dasarnya adalah bahwa setiap struktur dalam sistem sosial, fungsional terhadap yang lain. Sebaliknya kalau tidak fungsional maka struktur itu tidak akan ada atau akan hilang dengan sendirinya (James M. Henslin, 2007: 118)

Begitu pula dengan kajian Talcott Parsons dalam teori struktural fungsional ia melihat bahwa suatu masyarakat sebagai suatu sistem yang terdiri dari sub sistem yang saling berhubungan antara satu dengan yang lainnya. Dengan teori ini sebuah keluarga dianggap memiliki bagian yang terdiri dari adanya seorang ayah, seorang ibu, adanya anak-anak dan anggota keluarga lainnya. Setiap anggota disini dianggap sub sistemnya, yang tiap anggotanya memiliki fungsi masingmasing. Fungsi tersebut membawa konsekuensi tertentu bagi anggota keluarga dan bagi keluarga secara keseluruhan. Dalam hal ini dengan ketiadaan figur seorang ayah maka perannya akan digantikan oleh seorang ibu, dengan begitu tentu saja akan 
merubah fungsi-fungsi yang ada di dalam keluarga tersebut, dan akan membawa konsekuensi bagi para anggota yang ada didalamnya (George Ritzer: 2014: 117)

Kebertahanan single mother dalam merawat dan mengurus keluarga dengan sabar, mesra dan konsisten, ia mempertahankan hubungan-hubungan dalam keluarga. Single mother menciptakan suasana mendukung kelangsungan perkembangan anak dan semua kelangsungan keberadaan unsur keluarga lainnya. Seorang single mother yang sabar menanamkan sikap-sikap, kebiasaan pada anak, tidak panik dalam menghadapi gejolak didalam maupun diluar diri anak, akan memberi rasa tenang dan rasa tertampungnya unsurunsur keluarga. Terlebih lagi, sikap ibu yang mesra terhadap anak akan memberi kemudahan bagi anak yang lebih besar untuk mencari hiburan dan dukungan pada orang dewasa dalam diri ibunya. Para single mother sudah terlalu asyik dengan anak-anaknya sehingga lupa akan sosok seorang suami dan ayah untuk anak-anaknya.

Single mother dalam melanjutkan kehidupannya ada yang berhasil melewati permasalahan tanpa pasangan dalam hidup, tetapi tidak sedikit yang dapat melangsungkan hidup setelah ditinggalkan oleh pasangannya. Bagi wanita yang lemah ia akan langsung memikirkan bagaimana mencari pengganti suaminya dengan cepat tanpa berfikir panjang.

Banyak para perempuan single mother yang tidak tahan berlama-lama menjada karena berbagai alasan, salah satunya karena tidak sanggup membiayai kehidupannya dan anak-anaknya, ia membutuhkan banyak biaya untuk bertahan hidup. Beberapa single mother lainnya ada juga yang memilih bertahan dengan status single mothernya. Dalam penelitian ini ada beberapa single mother yang memutuskan tidak menikah setelah bercerai dan ditinggal mati oleh suaminya. Mereka menjalani hidup dengan status single mother sudah cukup lama, dan ada beberapa diantara mereka yang memang sudah tidak berniat untuk menikah lagi dengan laki-laki lain.

\section{Tabel 1}

Data single mother yang ada di Nagari Simalanggang

\begin{tabular}{|c|c|c|c|c|c|}
\hline \multirow{2}{*}{ No } & \multirow{2}{*}{$\begin{array}{l}\text { Nama } \\
\text { Single } \\
\text { Mother }\end{array}$} & \multicolumn{2}{|c|}{ Usia (th) } & \multirow{2}{*}{$\begin{array}{l}\text { Jumlah } \\
\text { Anak }\end{array}$} & \multirow{2}{*}{$\begin{array}{l}\text { Penye- } \\
\text { bab } \\
\text { Single } \\
\text { Mother }\end{array}$} \\
\hline & & $\begin{array}{c}\text { Waktu } \\
\text { Menjanda }\end{array}$ & 2019 & & \\
\hline 1 & $\begin{array}{l}\text { Ibu } \\
\text { EM }\end{array}$ & 42 & 46 & 3 & $\begin{array}{l}\text { Cerai } \\
\text { Mati }\end{array}$ \\
\hline 2 & $\begin{array}{l}\text { Ibu } \\
\text { GA }\end{array}$ & 40 & 61 & 5 & $\begin{array}{l}\text { Cerai } \\
\text { Mati }\end{array}$ \\
\hline 3 & $\begin{array}{l}\text { Ibu } \\
\text { EN }\end{array}$ & 39 & 50 & 3 & $\begin{array}{l}\text { Cerai } \\
\text { Mati }\end{array}$ \\
\hline 4 & Ibu RI & 40 & 46 & 3 & $\begin{array}{l}\text { Cerai } \\
\text { Hidup }\end{array}$ \\
\hline 5 & Ibu AS & 32 & 45 & 2 & $\begin{array}{l}\text { Cerai } \\
\text { Hidup }\end{array}$ \\
\hline
\end{tabular}

Dari data Tabel 1 di atas dapat dilihat penyebab single mother di Nagari Simalnggang Kecamatan Payakumbuh 3 orang disebabkan oleh kematian suami dan 2 orang lainnya disebabkan oleh perceraian. Dari 5data di atas single mother yang ada di Nagari Simalanggang Kecamatan Payakumbuh, mereka memutuskan tidak menikah lagi. Adapun alasan para single mother tersebut masih bertahan dengan statusnya adalah: Pertama, para single mother lebih memilih untuk membesarkan anak-anaknya sendiri dibanding harus menikah lagi dengan laki-laki lain. Karena menurutnya jika ia menikah lagi akan banyak menyita waktu dengan suami barunya dan takut 
anak-anak akan merasa kurang nyaman dengan keadaan tersebut, terlebih anakanaknya sudah ada yang remaja dan akan merasa canggung jika harus memiliki ayah baru. Seorang single mother juga berpendapat bahwa ia bahagia hidup dengan anak-anaknya tanpa sosok suami baru dan seorang ayah tiri dalam keluarganya. Pertimbangan lain juga diberikan oleh single mother yang memiliki anak gadis, karena itu membuat anak gadisnya tidak nyaman berada dirumah bersama dengan ayah tirinya, karena banyak kasus-kasus kekerasan dan pelecehan yang dilakukan oleh ayah tiri kepada anak tirinya. Hal tersebut yang membuat single mother yang memiliki anak gadis takut untuk menikah lagi.

Kedua, single mother sudah merasa nyaman dengan kesendiriannya tanpa seorang suami. Karena ia sudah terbiasa menjalani kehidupannya tanpa seorang suami selama bertahun-tahun. Dengan keadaan tersebut seorang single mother merasa cemas jika kebebasannya selama menjanda akan hilang ketika sudah bersuami lagi. Ia takut suami barunya melarang dan membatasi geraknya dalam menjalani kehidupan seperti saat menjanda. Banyak single mother yang merasa hidupnya saat ini bahagia, karena kemanapun ia pergi tidak perlu mendapatkan izin dari suami.

Ketiga, single mother yang dipisahkan oleh kematian takut jika suami barunya tidak sama seperti almarhum suaminya dulu, baik itu dari sifat, karakter dan bagaimana suami barunya tersebut memperlakuan ia dengan anak-anaknya. Karena yang memisahkan mereka adalah kematian, jadi susah untuk melupakan almarhum suaminya, berbeda dengan single mother yang dipisahkan oleh perceraian, perceraian tersebut yang disebabkan karena adanya permasalahan dalam rumah tangga yang membuat seorang single mother mudah untuk menggantikan posisi mantan suaminya.

Keempat, single mother sudah dipelihara oleh anak-anaknya yang sudah bekerja, jadi ia sudah tidak perlu cemas lagi dalam menjalani kehidupannya sehari-hari, dan ia tidak perlu cemas dengan masalah ekonomi karena sudah ada anak yang menanggung segala kebutuhan ibunya. Dengan memiliki anak-anak yang masih tinggal bersama dan sudah bekerja maka anaknya tersebut yang membantu untuk memenuhi kebutuhan hidupnya sehari-hari.

Kelima, single mother optimis bisa menghidupi dan mendidik anak-anaknya sendiri tanpa harus menikah lagi dan menggantungkan hidup dengan suami barunya. Karena ia tidak ingin merasa berhutang budi kepada orang lain untuk membesarkan dan merawat anakanaknya. Mereka yakin dengan fokus kepada anak-anaknya, membuat mereka bahagia jika suatu saat melihat anakanaknya sukses karena perjuangannya sendiri, bukan dengan bantuan orang lain termasuk suami barunya jika ia menikah lagi.

Keenam, single mother takut jika suami barunya hanya menyayangi dirinya saja tanpa menyayangi dan peduli kepada anak-anaknya. Kecemasan ini yang membuat para single mother takut untuk menikah lagi, mereka takut jika setelah menikah suami barunya menyia-nyiakan anak-anaknya, terlebih jika anak-anaknya masih kecil atau masih dibawah umur. Jika anak-anaknya sudah remaja atau dewasa mereka takut situasi tersebut membuat anak-anaknya stress memiliki 
ayah baru dan membuat anak-anaknya menjadi anak yang pembangkang kepada orang tua.

Ketujuh, single mother dilarang menikah oleh anak-anaknya, karena banyak dari anak-anaknya yang tidak setuju bahkan tidak suka jika harus memiliki ayah baru. Mereka belum siap menggantikan sosok ayah kandung mereka dengan seorang ayah tiri, karena takut terjadi hal-hal yang tidak baik dalam keluarga. Para anak juga takut jika ibu mereka tersakiti setelah menikah lagi, banyak kecemasan-kecemasan yang ada dalam pikiran anak-anaknya dan mereka tidak siap jika harus memanggil orang lain dengan sebutan "ayah". Banyak dari anak gadis yang takut untuk memiliki ayah tiri, mereka takut ayah tiri tersebut berbuat hal yang tidak baik kepadanya dan kepada keluarganya, perasaan yang demikian yang menyebabkan banyak dari anak-anak yang tidak mengizinkan ibu mereka untuk menikah lagi.

Kedelapan, trauma akan kegagalan, perceraian pasti berdampak pada mental serta psikis tidak hanya pasangan tapi juga anak. Jika faktor penyebab perceraian adalah hadirnya orang ketiga maka bisa dipastikan tidak mudah bagi seorang single mother untuk mengakhiri status jandanya. Jangankan untuk menikah lagi mencoba menjalin hubungan dengan pria yang baru saja tidak dilakukan. Rasa kecewa serta bayang-bayang masa lalu menjadi menakutkan dalam memulai suatu hubungan. Single mother merasa takut untuk menikah lagi, karena mereka takut jika hal yang terjadi dimasa lalu bersama dengan mantan suami terulang lagi pada masa yang akan datang dan itu menyebabkan mereka enggan dan tidak ingin menikah lagi.

\section{Masalah yang Dihadapi oleh Single Mother}

Peran perempuan saat ini tidak lagi hanya sebagai seorang yang bekerja dalam ranah domestik saja tetapi kini telah berkembang juga menjadi seseorang yang juga bekerja dalam ranah pubilk. Perubahan yang terjadi pada seorang single mother yang awalnya menjadi seorang ibu dan isteri kini berubah mejadi ibu sekaligus ayah yang tidak hanya mendidik, merawat, mengasuh anaknya tapi kini juga harus mencari nafkah keluarga. Kondisi ini tidak menyurutkan semangat perempuan single mother, mereka tetap melanjutkan dan memperbaiki hidupnya untuk kembali membangun keluarga secara harmonis. Peran single mother sebagai kepala keluarga sangatlah penting, dimana ia akan melakukan tugas gandanya sebagai kepala keluarga yang memliki kewajiban untuk memenuhi kebutuhannya serta kebutuhan anak-anaknya dan juga ia harus berperan sebagai seorang ibu yang mendidik anak-anaknya sekaligus juga melakukan pekerjaan rumah tangga (Paramitha, 2018: 4)

Menjadi seorang single mother tentu berat bagi seorang perempuan untuk menjalankan dua peran sekaligus. Sehingga peran-peran yang dilaksanakan oleh seorang single mother akan muncul beberapa masalah yang dihadapinya dalam menjalani kehidupannya seharihari. Berikut beberapa masalah yang sering terjadi pada single mother:

\section{Masalah Ekonomi}

Ekonomi dalam kehidupan merupakan faktor utama dan penentu dalam menentukan kemakmuran individu 
dalam masyarakat, karena dengan ekonomi akan terjaga kelangsungan hidup masyarakat. Didalam penelitian ini ekonomi menjadi faktor utama yang menjadi permasalahan dalam keluarga single mother. Ekonomi sangat berkaitan dengan pemenuhan kebutuhan seharihari dalam keluarga. Rendahnya perekonomian yang di dapatkan oleh seorang single mother membuat mereka kesulitan dalam memenuhi kebutuhannya sehari-hari (Dini Mutia: 8)

Kondisi ketidakmampuan secara ekonomi untuk memenuhi standar hidup rata-rata dalam keluarga membuat para single mother harus bekerja lebih giat lagi. Kondisi ketidakmampuan ini ditandai dengan rendahnya kemampuan pendapatan untuk memenuhi kebutuhan pokok baik berupa pangan, sandang, maupun papan.

Masalah ekonomi yang dialami oleh kelurga juga mempengaruhi terhadap perceraian. Dilihat dari kasus perceraian alasan paling dominan penyebab perceraian adalah kemiskinan. Perempuan dan anak-anak rentan ditinggal suami tanpa diberikan nafkah, ini salah satu jalan bagi laki-laki mengelak dari beban ekonomi (Hanani, 2013: 31). Dengan demikian para single mother tidak bisa terlalu mengharapkan nafkah dari mantan suami untuk kelanjutan hidup anak-anaknya. Mereka tidak bisa mengharapkan nafkah penuh dari mantan suami seperti sebelum mereka bercerai.

Bagi single mother yang disebabkan oleh perceraian, mereka tidak mendapatkan dukungan dan nafkah dari mantan suaminya untuk memenuhi kebutuhan anak-anaknya, karena itu perempuan lah yang harus mencukupi dan mencari nafkah untuk memenuhi kebutuhannya dan kebutuhan anakanaknya sampai sang anak dewasa. Sehingga single mother yang harus matimatian banting tulang untuk membesarkan anak-anaknya sendiri tanpa bantuan dari mantan suaminya (Hanani, 2018, 78).

Seorang single mother harus mendidik dan membesarkan anaknya sendiri dengan baik, agar anak tersebut selalu berbakti pada ibunya, dan semaksimal mungkin seorang single mother memberikan pendidikan sampai jenjang yang lebih tinggi. Tidak peduli mereka harus bekerja banting tulang, yang terpenting bagi mereka adalah pendidikan dan kebutuhan anak terpenuhi.

Para single mother bekerja merupakan pilihan yang harus mereka jalani demi memenuhi kebutuhan hidup keluarganya. Mendidik dan membesarkan anak adalah tujuannya untuk menjadikan anak lebih bersemangat lagi dalam berprestasi. Mereka juga tidak lupa untuk berdo'a, beribadah dan terus berusaha dengan semangat menjalani hidupnya ( Layliyah, 2013: 95)

Keluarga single mother di Nagari Simalanggang, penghasilan sangat penting dalam menunjang ekonomi keluarga, dimana orang tua dalam hal memenuhi kebutuhan keluarga dan pendidikan anak hanya melakukannya seorang diri tanpa pasangannya. Namun terkadang ada kesulitan yang secara langsung maupun tidak langsung dapat mempengaruhi pelaksanaan fungsi ekonomi keluarga. Adapun faktor ekonomi yang menjadi permasalahan didalam keluarga single mother disini yaitu mencakup tentang pekerjaan dan penghasilan yang didapatkan oleh 
keluarga tersebut.

Dari hasil penelitian, ada beberapa yang bisa dilakukan oleh para single mother untuk mengatasi masalah tersebut, untuk memenuhi kebutuhannya banyak diantara mereka yang bekerja membuka usaha, ada yang menjahit, membuka kedai sarapan pagi dan ada yang beternak. Semua pekerjaan tersebut dilakukan oleh para single mother sematamata untuk mencari nafkah untuk memenuhi kebutuhan hidup keluarganya.

\section{Masalah Psikologis}

Para perempuan single mother serring menemui permasalahan psikologis. Karena pada dasarnya masalah psikologis menyangkut masalah jiwa atau kepribadian seseorang. Menjadi seorang single mother memang sangat berat bagi seorang perempuan untuk menangani dan bertanggung jawab sepenuhnya kepada anak-anak dan keluarga serta mengambil alih seluruh tanggung jawab yang dipegang oleh seorang suami atau ayah bagi anak-anaknya.

Untuk mengatasi masalah tersebut para single mother berusaha menyibukkan diri dan sering berbagi pada anakanaknya, mereka saling sharing tentang masalah yang mereka hadapi di dalam keluraga, dengan demikian mereka tidak akan terlalu terbebani oleh persoalanpersoalan hidup yang mereka jalani.

\section{Masalah dalam Kehidupan Sosial}

Masalah yang menonjol pada single mother cerai hidup dalam kehidupan sosial adalah pada aspek kemampuan berkomunikasi, bertingkahlaku dan berhubungan dengan orang lain. Masalah yang muncul pada aspek ini adalah tidak ingin mengikuti kegiatan sosial bersama ibu-ibu di lingkungan. Masalah sosial yang dialami single mother adalah mereka akan menemukan dirinya tidak ada tempat di antara orang yang memiliki pasangan kecuali mereka diundang untuk bergabung dalam kegiatan sosial yang ada dalam masyarakat. Pada single mother cerai mati masalah yang menonjol terkait aspek hubungan dengan jenis kelamin lain dan pemahaman aturan pergaulan dalam masyarakat. Masalah yang muncul pada aspek ini adalah merasa tidak pantas untuk menikah lagi. Pada usia lanjut, keinginan untuk tidak menikah lagi bisa disebabkan oleh perasaan malu dengan anak atau anggapan masyarakat, atau karena ragu dengan kemampuan seksual ( Maylani, 2013: 79)

\section{KESIMPULAN}

Menjadi single mother adalah yang pertama karena perceraian, dimana suami dan isteri sepakat untuk berpisah dan tidak hidup bersama lagi menjalani kehidupan sehari-hari. Kedua karena suami meninggal dunia, baik itu meninggal dunia karena alasan kecelakaan maupun karena sakit. Isteri harus menjadi orang tua tunggal antuk membesarkan dan mendidik anakanaknya tanpa seorang suami.

Alasan-alasan single mother bertahan dengan status single mothernya tersebut diantaranya adalah para single mother tersebut lebih memilih untuk fokus membesarkan anak-anaknya sendiri dari pada manikah lagi, mereka juga sudah sangat merasa nyaman dengan kesendiriannya tanpa sosok seorang suami, bagi single mother yang ditinggal mati, kesendirian tersebut juga 
disebabkan oleh kecintaannya pada almarhum suaminya yang menyebabkannya susah untuk mendapatkan pengganti yang baru. Ada juga sebagian single mother yang sudah ditanggung oleh anak-anaknya karena sebagian dari anaknya sudah bekerja dan sudah mampu untuk menanggung kehidupan keluarga. Para single mother optimis mereka bisa menghidupi anakanaknya sendiri tanpa bantuan orang lain dan mereka juga tidak mau merasa berhutang budi kepada orang lain. Ada juga yang berpendapat bahwa suami barunya tidak menyayangi anak-anaknya, ia takut jika suami barunya tersebut menelantarkan anak-anaknya dan tidak memperdulikan kehidupan dan masa depan anak-anaknya. Yang biasa terjadi adalah kebanyakan anak-anak dari single mother tersebut melarang ibunya untuk menikah lagi dengan alasan mereka tidak ingin dan tidak suka memiliki ayah baru dan sosok yang menggantikan ayah kandungnya. Bagi single mother yang berpisah karena perceraian mereka takut jika menikah lagi, pernikahannya tersebut akan gagal seperti pernikahan sebelumnya.

Maasalah yang dihadapi oleh para single mother yaitu masalah perekonomian dan masalah psikologis, tapi yang menjadi permasalahan utama dalam kehidupan rumah tangga single mother adalah masalah perekonomian, karena mereka membutuhkan perekonomian yang cukup untuk memenuhi kehidupan sehari-hari. Banyak cara yang dilakukan oleh para single mother dalam mengatasi permasalahan ekonomi ini, salah satunya adalah dengan membuka usaha seperti menjahit, membuka kedai sarapan pagi dan beternak.

\section{REFERENSI}

Anjela, Marisa. 2014. Pergeseran Peran Mamak Terhadap Kemenakan Dalam Adat Minangkabau Di Kenagarian Simalanggang. Jurnal Jom Fisip. Vol 1 No. 2

Cahyani, Kurnia Dwi. 2016. Masalah Dan Kebutuhan Orang Tua Tunggal Sebagai Kepala Keluarga. E-Journal Bimbingan Konseling Edisi 8 tahun ke-5

Fadillah, Nur. 2015. Peran Ibu 'Single Parent" Dalam Menumbuhkan Kemandirian Anak Di Desa Bojong Timur Magelang.Skripsi. Fakultas Ilmu Sosial Universitas Negeri Semarang

Hanani, Silfia. 2013.Tanah Ulayat dan Kemiskinan Perempuan. Jurnal Qafa'ah. Vol 3 No 1

Hanani, Silfia. 2018. Woman's Newspapers As Minangkabau Feminist MovementAgaints Marginalization In Indonesia. Jurnal GJAT. Vol 8 No 2

Henslin, James M.2007. Sosiologi dengan Pendekatan Membumi. Jakarta: PT Gelora Aksara Pratama

Husaini, Usman. 2017. Metodologi Penelitian Sosial. Jakarta: Bumi Aksara

Layliyah, Zahrotul. 2013. Perjuangan Hidup Single Mother. Jurnal Sosiologi Islam. Vol 3 No 1

Maripadang, Sarnita.2013. Peran Single Parent Dalam Menjalankan Fungsi Keluarga. Skripsi: Universitas Hasanuddin 
Maylani, Irma dan Afrizal Sano. 2013. Permasalahan Yang Dihadapi Single Parent Di Jorong Kandang Harimau Kenagarian Sijunjung dan Implikasinya Terhadap Layanan Konseling. Jurnal Ilmiah Konssseling. Vol 2 No 1

Sunarti, Euis. 2001. Fungsi dan Peran Keluarga. Disertasi: Institut Pertanian Bogor

Mutia Rika, Dini dan Risdayati. 2010."Peran Perempuan Single Parent Dalam Menjalankan Fungsi Keluarga. (Studi di Perumahan Wadya Graha II Kelurahan Delima Kecamatan Tampan Kota Pekanbaru)". Jurnal Dini Perempuan Single Parent.
Paramitha, Dyan. 2018. Peran Single Parent Dalam Mengasuh Anak di Kecamatan Maritengngae Kabipaten Sidrap. Jurnal Ilmiah Pendidikan Antropologi Universitas Negeri Makasar

Ritzer, George. 2014. Teori Sosiologi Modern. Jakarta: Pranadamedia Group 
